\title{
Effect of nitric oxide on rat adrenal zona fasciculata steroidogenesis
}

\author{
C B Cymeryng, L A Dada and E J Podestá
}

Departamento de Bioquímica, Facultad de Medicina, Universidad de Buenos Aires Paraguay 2155 (1121), Buenos Aires, Argentina.

(Requests for offprints should be addressed to C B Cymeryng, Departamento de Bioquímica, Facultad de Medicina, Universidad de Buenos Aires Paraguay 2155, 5ํㅜ piso (1121), Buenos Aires, Argentina)

\begin{abstract}
The present study was designed to investigate the role of nitric oxide (NO) in the regulation of adrenocortical function. Different NO donors, such as sodium nitroprusside (SNP), S-nitroso-L-acetyl penicillamine, diethylamine/NO complex sodium salt and diethylenetriamine NO adduct, significantly decreased corticosterone production both in unstimulated and in corticotropin-stimulated zona fasciculata adrenal cells, in a dose-dependent manner. The effect of SNP was reversed by ferrous hemoglobin. A selective inhibitor of $\mathrm{NO}$ synthase, $\quad \mathrm{L}-\mathrm{N}^{\mathrm{G}}$-nitro-arginine significantly increased corticosterone secretion. The effect of SNP was not
\end{abstract}

mediated by cGMP as permeable cGMP analogs did not reproduce its inhibitory effect. SNP significantly inhibited the steroidogenesis stimulated by $8 \mathrm{Br}-\mathrm{cAMP}$ and $22(\mathrm{R})-$ $\mathrm{OH}$-cholesterol, but was ineffective when corticosterone was produced in the presence of exogenously added pregnenolone. Moreover, the conversion of $\left[{ }^{3} \mathrm{H}\right]$ cholesterol to $\left[{ }^{3} \mathrm{H}\right]$ pregnenolone and the production of pregnenolone or progesterone (assessed by RIA) were significantly decreased by SNP. Taken together, these results suggest that $\mathrm{NO}$ may be a negative modulator of adrenal zona fasciculata steroidogenesis.

Journal of Endocrinology (1998) 158, 197-203

\section{Introduction}

Nitric oxide (NO), synthesized from L-arginine by the enzyme NO synthase (NOS), is a small, gaseous and reactive molecule that has been found to be involved in the regulation of a wide range of biological functions as an intercellular and intracellular signal. Among others, its role as a neurotransmitter has been demonstrated in the central and peripheral nervous system, as well as a regulator of vasodilatation and normal vascular tone, and as a cytotoxic agent in immunological reactions (Moncada et al. 1991, Nathan 1992, Bredt \& Snyder 1994). Some actions of NO result from binding to the iron atom in the heme group of guanylate cyclase, which stimulates the production of cGMP. Moreover, NO can also bind to nonheme iron in numerous enzymes and modify its activity (Ignarro 1989, Snyder \& Bredt 1991) .

Increasing evidence suggests that $\mathrm{NO}$ participates in endocrine modulation, being implicated in the control of the hypothalamo-pituitary axis (Ceccatelli et al. 1993, Rettori et al. 1993, Duvilansky et al. 1995) and in the activity of pancreatic $\beta$-islets (Schmidt et al. 1992).

In particular, several reports suggest that NO may be involved in the regulation of steroid biosynthesis. It has been shown that NO inhibits steroidogenesis in granulosaluteal cells (Van Voorhis et al. 1994, Dave et al. 1997) and human chorionic gonadotropin (hCG)-induced steroidogenesis in both MA-10 and rat Leydig cells (Del Punta et al. 1996). Moreover, arginine analogs such as $\mathrm{N}^{\mathrm{G}}$ monomethyl-L-arginine (L-NMMA) and $\mathrm{N}^{\omega}$-nitro-Larginine-methyl ester (L-NAME) that inhibit NOS activity increase basal and hCG-stimulated testosterone production by interstitial cells. This effect could not be attributed to cAMP accumulation nor to any alteration on specific hCG binding (Welch et al. 1995).

As for the adrenal gland, NOS activity in cytosol and stimulation of a soluble guanylate cyclase activity induced by $\mathrm{NO}$ were demonstrated in rat whole adrenal, bovine cortex and medulla cytosol (Palacios et al. 1989). However, the role of $\mathrm{NO}$ in the regulation of adrenal steroidogenesis remains controversial. Adams et al. (1991) reported that in vivo treatment with L-NAME resulted in a dosedependent increase in testosterone and corticosterone secretion without any effect at the anterior pituitary level, but an increase in plasma adrenocorticotropin (ACTH) concentrations induced by the administration of L-NAME in vivo was also described (Giordano et al. 1996). On the contrary, it has been reported that corticosterone secretion in isolated perfused adrenals is inhibited by L-NAME (Cameron \& Hinson 1993). Concurrently, Nakayama et al. (1996) found that L-NMMA prevented the ACTHstimulated production of aldosterone in isolated rat adrenal glands. Recently, however, a direct inhibitory effect of $\mathrm{NO}$ on angiotensin II and ACTH-induced aldosterone synthesis in rat and human adrenal glomerulosa cells was reported by Natarajan et al. (1997). The present study was 
intended to assess the effect of $\mathrm{NO}$ on basal and ACTHstimulated corticosterone production in isolated adrenal cells. Its mechanism and possible site of action along the steroidogenic pathway were also examined.

\section{Materials and Methods}

\section{Chemicals}

ACTH (lyophilized), was obtained from Elea Laboratories, Buenos Aires, Argentina, 9- $\alpha$-fluoro-11- $\beta, 17,21$-trihydroxy-16- $\alpha$-methylpregna-1,4-diene-3,20-dione (dexamethasone) was from Fluka, A. G., Buchs, Switzerland, 8-bromo cyclic AMP (8Br-cAMP), 8-bromo cyclic GMP (8Br-cGMP), dibutyryl cyclic GMP (db-cGMP), 22(R)$\mathrm{OH}$-cholesterol, ferrous hemoglobin, pregnenolone and sodium nitroprusside (SNP) were purchased from Sigma Chemical Co. (St Louis, MO, USA). S-nitroso-Nacetyl-penicillamine (SNAP), diethylamine/NO complex sodium salt (DEA/NO), diethylenetriamine $\mathrm{NO}$ adduct (DETA/NO), and $\mathrm{L}^{-\mathrm{N}^{\mathrm{G}}}$-nitro-arginine (L-NNA) were purchased from Research Biochemicals International (Natick, MA, USA). $\left[7-{ }^{3} \mathrm{H}\right]$ Cholesterol $(10-$ $30 \mathrm{Ci} / \mathrm{mmol}), \quad\left[1,2,6,7-{ }^{3} \mathrm{H}\right]$ progesterone, $\quad\left[1,2,6,7-{ }^{3} \mathrm{H}\right]$ corticosterone and $\left[7-{ }^{3} \mathrm{H}\right]$ pregnenolone were from New England Nuclear (Boston, MA, USA). Progesterone and corticosterone antisera were provided by Dr A Bélanger, Laval University, Quebec, Canada. Pregnenolone antiserum was a kind gift of Dr S Campo, Hospital de Niños, Buenos Aires, Argentina. All other reagents were commercial products of the highest grade available.

\section{Animals}

Adult Wistar rats were used throughout the experiments. Animals had free access to water and Purina formula chow. Dexamethasone was supplied in the drinking water $(10 \mu \mathrm{g} / \mathrm{ml}) 16 \mathrm{~h}$ before killing. Animals were killed by decapitation according to protocols for animal use approved by the institutional animal care and use committee that follow NIH guidelines. Adrenals were rapidly excised and kept on ice.

\section{Zona fasciculata cell preparation and treatment}

Preparation of zona fasciculata cells followed published procedures (Neher \& Milani 1978). Cells were suspended in Krebs-Ringer bicarbonate buffer $(\mathrm{pH} 7 \cdot 4)$ under $\mathrm{O}_{2} / \mathrm{CO}_{2}(95: 5 \%)$, containing $10 \mathrm{mM}$ glucose, $0 \cdot 5 \%(\mathrm{w} / \mathrm{v})$ BSA and $0.1 \mathrm{mM}$ 3-isobutyl-1-methylxanthine and aliquoted in $1 \mathrm{ml}$ fractions containing $10^{5}$ cells per tube.

SNP, SNAP, DEA/NO and DETA/NO were freshly prepared just before use. SNP was dissolved in acetate buffer $50 \mathrm{mM} \mathrm{pH} \mathrm{5,} \mathrm{SNAP} \mathrm{was} \mathrm{dissolved} \mathrm{in} \mathrm{dimethyl}$ sulfoxide (DMSO). DEA/NO and DETA/NO were dissolved in incubation buffer. Equivalent amounts of acetate buffer, DMSO $(0.1 \%)$ or incubation buffer were added to the controls as vehicle. According to the manufacturer, the half-lives of dissociation for DEA/NO and SNP are in the range of minutes, while for DETA/NO and SNAP they are 20 and $26 \mathrm{~h}$ respectively.

Preincubations in the presence of SNP, SNAP, DEA/NO or DETA/NO were carried out for $15 \mathrm{~min}$ at $37^{\circ} \mathrm{C}$, then ACTH or other stimuli were added to the cell suspensions. In another set of experiments cell suspensions were preincubated in the presence of $0.1 \mathrm{mM} \mathrm{L}-\mathrm{NNA}$ for $30 \mathrm{~min}$. After the appropriate additions, incubations proceeded for $60-90 \mathrm{~min}$ at $37^{\circ} \mathrm{C}$, with shaking (100 cycles/ $\mathrm{min})$. Incubations were stopped by cooling the tubes in ice/water and cells were pelleted by centrifugation at $500 \mathrm{~g}$ for $15 \mathrm{~min}$. Supernatants were assayed for corticosterone by RIA after extraction with methylene chloride. Cell viability was assessed by the Trypan Blue dye exclusion test as determined by microscopy. Briefly, the cell pellets were resuspended in Krebs-Ringer bicarbonate buffer and aliquots of the suspensions were diluted 1:1 with the Trypan Blue solution $(0 \cdot 4 \%)$. Counting of the cells (approximately 100 cells per tube in each case) was performed within $5 \mathrm{~min}$.

\section{Side-chain cleavage cytochrome P450 activity}

Incubation of adrenal quarters with SNP were performed in Krebs-Ringer bicarbonate buffer $(\mathrm{pH} 7 \cdot 4)$ containing $10 \mathrm{mM}$ glucose for $15 \mathrm{~min}$, followed by a $20 \mathrm{~min}$ incubation in the presence of ACTH. Adrenals were homogenized in $0.32 \mathrm{M}$ sucrose and the mitochondrial fraction was obtained by differential centrifugation. Mitochondrial pellets were suspended in $10 \mathrm{mM}$ Tris, $0 \cdot 25 \mathrm{M}$ sucrose, $0.4 \mathrm{mM} \quad \beta$-mercaptoethanol, $0.1 \mathrm{mM}$ EDTA, $5 \mathrm{mM} \mathrm{MgCl}{ }_{2} \mathrm{pH} \mathrm{7 \cdot 4}$ and $100 \mu \mathrm{l}$ aliquots were used per tube (approximately $0.4 \mathrm{mg}$ protein $/ \mathrm{ml}$ ). After the addition of $50 \mu \mathrm{M}$ cyanoketone, in order to block pregnenolone metabolism (Farese et al. 1970), and $\left[{ }^{3} \mathrm{H}\right]$ cholesterol $(1-2 \mu \mathrm{Ci} / \mathrm{ml})$, mitochondrial fractions were preincubated for $25 \mathrm{~min}$ at room temperature (final volume $150 \mu \mathrm{l})$. The reaction was started by addition of $100 \mu \mathrm{NADPH}(1 \mathrm{mM})$. After $20 \mathrm{~min}$ at $37^{\circ} \mathrm{C}$, the tubes were placed in an ice/water bath. The $\left[{ }^{3} \mathrm{H}\right]$ pregnenolone recovery of extraction with methylene chloride (70-80\%) was determined by adding a tracer amount of $\left[{ }^{14} \mathrm{C}\right]$ pregnenolone (5000 d.p.m.). The organic phase was evaporated and the dried residue reconstituted in methylene chloride, spotted on silica gel plates and developed using cyclohexane:ethyl acetate $(3: 2)$ as the mobile phase. The position of pregnenolone was revealed by placing the plates in an iodine-saturated chamber. Silica was scraped off each $1 \mathrm{~cm}$ section and subjected to liquid scintillation counting (Romero et al. 1996). Results were expressed as the pregnenolone fraction of total radioactivity, corrected by recovery, per $\mathrm{mg}$ of mitochondrial protein. 
Assessment of pregnenolone and progesterone production

Adrenal quarters were preincubated as previously described, in the presence of $1 \mathrm{mM}$ SNP for $15 \mathrm{~min}$, and then incubated for $20 \mathrm{~min}$ after addition of ACTH. Mitochondrial fractions were obtained and resuspended as before. To determine pregnenolone production in control and SNP-treated mitochondrial fractions, $50 \mu \mathrm{M}$ cyanoketone was added to the incubation mix, and tubes were incubated in the presence of NADPH $(1 \mathrm{mM})$ for $30 \mathrm{~min}$ at $37^{\circ} \mathrm{C}$, in a $150 \mu \mathrm{l}$ volume. The reaction was stopped by placing the tubes in an ice/water bath. Pregnenolone was extracted with $1.5 \mathrm{ml}$ cyclohexane and suitable aliquots were used for RIA. To assess progesterone production, cyanoketone was substituted in the experimental protocol by the inhibitors of progesterone metabolism (Neher et al. 1982): metopyrone $(0.27 \mathrm{mM})$ and $1-(\beta$-guanidinoethyl)3-(4-pyridyl)indole sulfate ( $\mathrm{Ba} 40.028) \quad(1.6 \mathrm{mM})$ as inhibitors of $11 \beta-, 18-$ and 19-hydroxylation, and 21hydroxylation respectively. At the end of the incubation progesterone was extracted with cyclohexane and its concentration estimated by RIA.

\section{Statistical analysis}

Data points represent mean \pm S.E.M. Statistical analysis was performed by Student's $t$-test, one-way analysis of variance (ANOVA) followed by Dunnett's test or two-way analysis of variance (MANOVA) followed by Tukey's test where indicated.

\section{Results}

In order to evaluate the effect of in vitro treatment with SNP on isolated adrenal cells, corticosterone production, in basal conditions, was assessed in the presence of increasing concentrations of SNP $(20 \mu \mathrm{M}-1 \mathrm{mM})$. Corticosterone accumulation was significantly decreased by SNP with a threshold concentration of $100 \mu \mathrm{M}$ (Fig. 1A). Hemoglobin (an NO trapping agent), which was ineffective per se, completely prevented the effect of $1 \mathrm{mM}$ SNP (Fig. 1B).

SNP significantly inhibited steroidogenesis in ACTHstimulated zona fasciculata cells, starting at $50 \mu \mathrm{M}$, in a dose-dependent manner (Fig. 2A) and corticosterone production induced by different concentrations of ACTH was significantly decreased by $1 \mathrm{mM}$ SNP (Fig. 2B). SNAP, DEA/NO and DETA/NO also produced a significant inhibition of basal and submaximally ACTHstimulated steroidogenesis as shown in Fig. 3.

The percentage of viable cells was assessed in each experiment and it was not significantly different for SNP, SNAP, DEA/NO or DETA/NO at the highest concentration used $(84 \pm 4 \%, 86 \pm 5 \%, 83 \pm 4 \%$ and $87 \pm 3 \%$ respectively), in comparison with control cells ( $87 \pm 5 \%)$. Similar results were obtained in the presence of ACTH (data not shown).
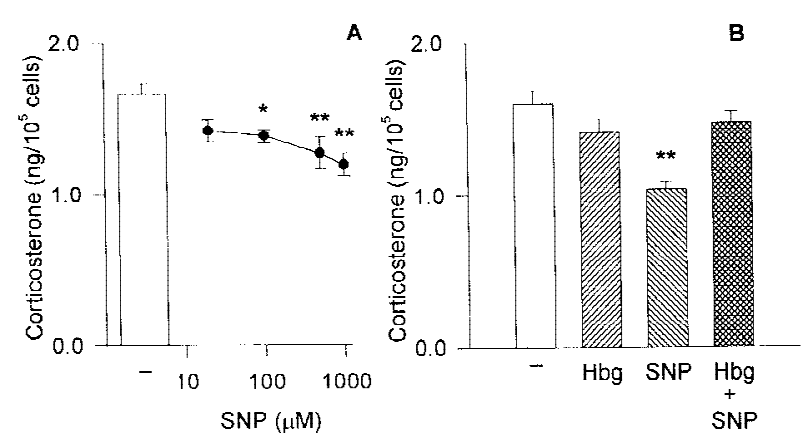

Figure 1 Effect of SNP on corticosterone secretion in rat adrenal zona fasciculata cells. Unstimulated cells were incubated for $60 \mathrm{~min}$ at $37^{\circ} \mathrm{C}$ in the presence of increasing concentrations $(20 \mu \mathrm{M}-1 \mathrm{mM})$ of SNP (A) or $1 \mathrm{mM} \mathrm{SNP}$ with or without hemoglobin $(\mathrm{Hbg}, 50 \mu \mathrm{M})(\mathrm{B})$. Corticosterone production was assessed by RIA. Each bar or point represents the mean \pm S.E.M. of three independent experiments each performed in triplicate. ${ }^{\star} P<0 \cdot 05,{ }^{* \star} P<0 \cdot 01$ vs control by Dunnett's test.
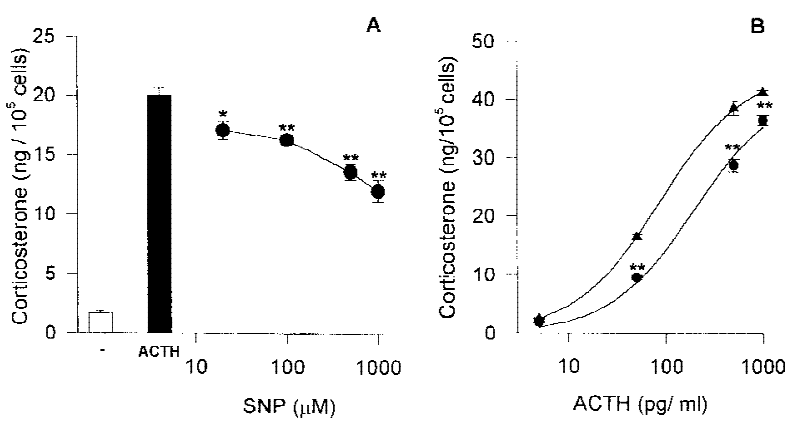

Figure 2 Effect of SNP on ACTH-stimulated corticosterone secretion in rat adrenal zona fasciculata cells. (A) Cells were preincubated with increasing concentrations of SNP

$(20 \mu \mathrm{M}-1 \mathrm{mM})$ for $15 \mathrm{~min}$ and further incubated with ACTH $(50 \mathrm{pg} / \mathrm{ml})$ for an additional $60 \mathrm{~min}$. Each bar or point represents the mean \pm S.E.M. of three independent experiments performed in triplicate. ${ }^{*} P<0.05,{ }^{*} P<0.01 \mathrm{vs} A C T H$, by Dunnett's test. (B) Cells were preincubated without $(\boldsymbol{\Delta})$ or with $1 \mathrm{mM} \mathrm{SNP}(\boldsymbol{\bullet})$ for $15 \mathrm{~min}$ and further incubated with increasing concentrations of ACTH $(5-1000 \mathrm{pg} / \mathrm{ml})$ for an additional $60 \mathrm{~min}$. Each point represents mean \pm S.E.M. of three independent experiments, performed in triplicate. ${ }^{*} P<0 \cdot 01$ vs ACTH alone by two-way ANOVA and Tukey's test

The participation of endogenously produced NO in the modulation of adrenal cell steroidogenesis was studied using a specific inhibitor of NOS. L-NNA significantly stimulated corticosterone production in control and submaximally ACTH-stimulated adrenal cells (Fig. 4). In the presence of L-arginine $(0.5 \mathrm{mM})$, which significantly inhibited both basal and ACTH-induced steroidogenesis, L-NNA stimulation was not observed (data not shown).

To study the role of cGMP as a second messenger of NO action, the effect of the permeable analogs of cGMP, $8 \mathrm{Br}-$ and $\mathrm{db}-\mathrm{cGMP}$ on adrenal steroidogenesis was examined. No inhibitory effect was observed for 8Br-cGMP either on basal or on ACTH-stimulated 
BASAL

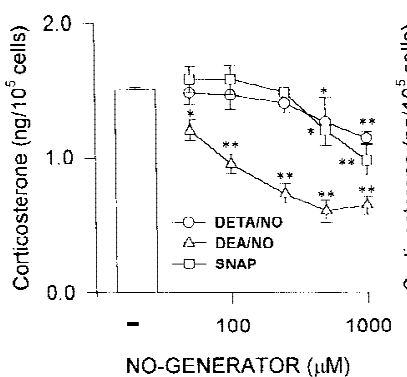

$\mathrm{ACTH}$

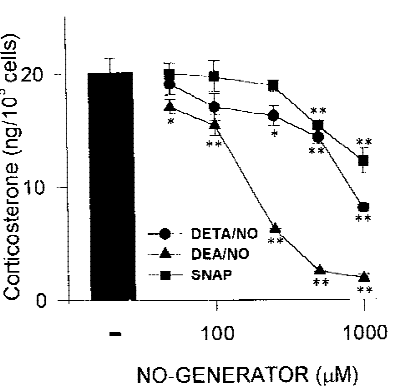

Figure 3 Effect of different $\mathrm{NO}$ donors on basal and ACTHstimulated corticosterone production by rat adrenal zona fasciculata cells. Cells were preincubated for $15 \mathrm{~min}$ with increasing concentrations of SNAP, DEA/NO or DETA/NO, and the incubation proceeded for $60 \mathrm{~min}$ in the absence or the presence of ACTH $(50 \mathrm{pg} / \mathrm{ml})$. Each point represents the mean \pm S.E.M. of three independent experiments, each performed in triplicate. ${ }^{*} P<0 \cdot 05 ;{ }^{*} P<0 \cdot 01$ without vs with $\mathrm{NO}$ donors by Dunnett's test.
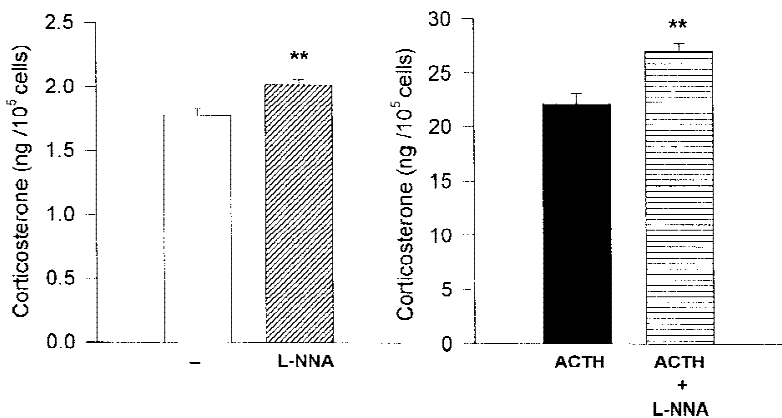

Figure 4 Effect of an inhibitor of NOS, L-NNA, on steroidogenesis in rat adrenal zona fasciculata cells. Cells were preincubated in the absence or in the presence of $0.1 \mathrm{mM}$ L-NNA for $30 \mathrm{~min}$. ACTH $(50 \mathrm{pg} / \mathrm{ml})$ was added where shown and incubation proceeded for $90 \mathrm{~min}$. Corticosterone was assessed by RIA. Each bar represents the mean \pm S.E.M. of three independent experiments, performed in triplicate. ${ }^{* *} P<0 \cdot 01$ vs basal or ACTH by Student's $t$-test.

corticosterone production (Table 1). 8Br-cGMP at $1 \mathrm{mM}$ produced an increase in basal steroidogenesis. db-cGMP was also unable to inhibit steroidogenesis (data not shown).

To investigate the possible site of inhibition of $\mathrm{NO}$, the effect of SNP on the biochemical steps involved in ACTH action was examined. As shown in Table 2, SNP inhibited adrenal steroidogenesis stimulated by $8 \mathrm{Br}-\mathrm{cAMP}$ or 22(R)-OH-cholesterol (a cholesterol analog that freely diffuses between the mitochondrial membranes). On the contrary, corticosterone production in the presence of exogenously added pregnenolone was not affected by SNP.

The conversion of $\left[{ }^{3} \mathrm{H}\right]$ cholesterol to $\left[{ }^{3} \mathrm{H}\right]$ pregnenolone was assessed in mitochondrial fractions from adrenal glands treated with ACTH in the presence or absence
Table 1 Effect of cGMP analogs on corticosterone accumulation in rat adrenal zona fasciculata cells. Cells were incubated for $60 \mathrm{~min}$ in the presence of $8 \mathrm{Br}$-cGMP alone or in combination with $\mathrm{ACTH}$. Corticosterone was assessed by RIA. Each value represents the mean \pm S.E.M. of four independent experiments performed in triplicate. Statistical analysis was performed by ANOVA for each group (e.g. control, ACTH)

\section{Additions \\ None \\ 8Br-cGMP $(0 \cdot 1 \mathrm{mM})$ \\ 8Br-cGMP $(1 \mathrm{mM})$ \\ ACTH $(50 \mathrm{pg} / \mathrm{ml})$ \\ ACTH $(50 \mathrm{pg} / \mathrm{ml})+8 \mathrm{Br}-\mathrm{cGMP}(0 \cdot 1 \mathrm{mM})$ \\ ACTH $(50 \mathrm{pg} / \mathrm{ml})+8 \mathrm{Br}-\mathrm{CGMP}(1 \mathrm{mM})$ \\ ${ }^{*} P<0.01$ vs control by Dunnett's test.}

Table 2 Effect of SNP on corticosterone synthesis under different stimuli. Adrenal zona fasciculata cells were preincubated in the absence or presence of SNP for $15 \mathrm{~min}, 22(\mathrm{R})-\mathrm{OH}$-cholesterol, $8 \mathrm{Br}$-cAMP or pregnenolone was added and incubation proceeded for another $60 \mathrm{~min}$. Corticosterone was assessed by RIA. Each value represents the mean \pm S.E.M. of four independent experiments performed in triplicate

Corticosterone (ng/10 $0^{5}$ cells)

\author{
Additions \\ None \\ $\mathrm{SNP}(1 \mathrm{mM})$ \\ 22(R)-OH-cholesterol $(5 \mu \mathrm{M})$ \\ 22(R)-OH-cholesterol $(5 \mu \mathrm{M})+\mathrm{SNP}(1 \mathrm{mM})$ \\ 8 Br-CAMP $\left(5 \times 10^{-6} \mathrm{M}\right)$ \\ $8 \operatorname{Br}-\mathrm{CAMP}\left(5 \times 10^{-6} \mathrm{M}\right)+\mathrm{SNP}(1 \mathrm{mM})$ \\ 8Br-CAMP $\left(10^{-4} \mathrm{M}\right)$ \\ 8Br-cAMP $\left(10^{-4} \mathrm{M}\right)+\mathrm{SNP}(1 \mathrm{mM})$ \\ Pregnenolone $(5 \mu \mathrm{M})$ \\ Pregnenolone $(5 \mu \mathrm{M})+\mathrm{SNP}(1 \mathrm{mM})$
}

Corticosterone

(ng/10 cells)

$1 \cdot 3 \pm 0 \cdot 2$

$1 \cdot 4 \pm 0 \cdot 1$

$3 \cdot 8 \pm 0 \cdot 4^{*}$

$18 \cdot 6 \pm 0 \cdot 6$

$21 \cdot 7 \pm 2.4$
${ }^{* *} P<0.01$ vs same treatment without SNP, by Student's $t$-test.

of $1 \mathrm{mM}$ SNP. The results shown in Fig. 5 indicate that while ACTH increased (1.8-fold) this conversion, SNP treatment resulted in a significant inhibition of $\left[{ }^{3} \mathrm{H}\right]$ pregnenolone synthesis, both in unstimulated and stimulated glands. Similar results were obtained when mitochondrial fractions, instead of whole adrenals, were directly exposed to SNP (data not shown). To further confirm these results, we analyzed pregnenolone or progesterone production by mitochondria from control and stimulated glands exposed to SNP. Mitochondrial fractions were incubated for $25 \mathrm{~min}$ with NADPH and cyanoketone (for pregnenolone estimation) or metopyrone and $\mathrm{Ba} 40.028$ (for progesterone determination). SNP significantly inhibited the production of both steroids as shown in Table 3. 


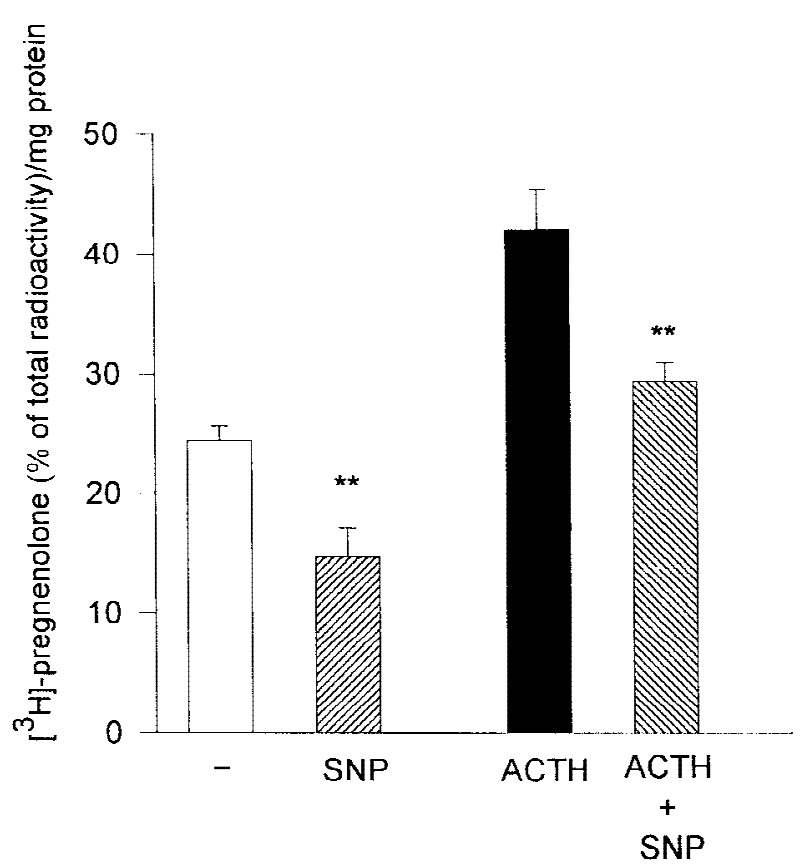

Figure 5 Effects of SNP on $\left[{ }^{3} \mathrm{H}\right]$ pregnenolone synthesis. Adrenal glands were preincubated with or without $1 \mathrm{mM}$ SNP for $15 \mathrm{~min}$ before addition of ACTH $(1 \mathrm{ng} / \mathrm{ml})$. Mitochondrial fractions, obtained as described elsewhere, were incubated in the presence of $\left[{ }^{3} \mathrm{H}\right]$ cholesterol $(1-2 \mu \mathrm{Ci} / \mathrm{ml})$, and cyanoketone $(50 \mu \mathrm{M})$ for $25 \mathrm{~min}$ at room temperature. NADPH $(1 \mathrm{mM})$ was added and incubation proceeded for $20 \mathrm{~min}$ at $37^{\circ} \mathrm{C}$. The incubation mix was extracted with methylene chloride and processed as described in Materials and Methods. Results are expressed as the pregnenolone fraction of total radioactivity, corrected by recovery, per mg of mitochondrial protein. Each bar represents the mean \pm S.E.M. of three independent experiments, performed in triplicate. ${ }^{* *} P<0.01$ without vs with SNP by Student's t-test.

\section{Discussion}

NO has been postulated as an autocrine/paracrine regulator of steroidogenesis in several tissues (Van Voorhis et al. 1994, Welch et al. 1995, Del Punta et al. 1996, Nakayama et al. 1996, Dave et al. 1997). The present results indicate that SNP, widely used as a NO generating compound (Moncada et al. 1991), significantly decreases rat adrenal corticosterone synthesis.

In the present study the inhibitory effect of SNP on steroidogenesis is probably associated with the release of $\mathrm{NO}$, as different NO donors, such as SNAP, DEA/NO and DETA/NO, also produced a significant inhibition of corticosterone biosynthesis. Moreover, the addition of ferrous hemoglobin, which binds free NO, as reported in several studies (Bredt \& Snyder 1989, Ignarro 1989, Del Punta et al. 1996, Ientile et al. 1996) prevented SNP inhibition, ruling out a deleterious effect of the ferrocyanide ions generated by SNP breakdown.

The fact that no changes in cell viability were observed for any of the doses of SNP, nor for the other NO donors,
Table 3 Effect of SNP on pregnenolone or progesterone production by mitochondrial fractions. Adrenal glands were preincubated without or with SNP for 15 min and further incubations, without or with ACTH, proceeded for an additional $30 \mathrm{~min}$. Mitochondrial fractions were incubated in the presence of cyanoketone $(50 \mu \mathrm{M})$ and $\mathrm{NADPH}(1 \mathrm{mM})$ for $30 \mathrm{~min}$ at $37^{\circ} \mathrm{C}$, in a $150 \mu \mathrm{l}$ volume. To assess progesterone production, cyanoketone was substituted by metopyrone $(0.27 \mathrm{mM})$ and $\mathrm{Ba} 40.028$ (1.6 mM). Both steroids were assessed by RIA. Each point represents the mean \pm S.E.M. of three independent experiments, performed in triplicate.

\begin{tabular}{|c|c|c|}
\hline & $\begin{array}{l}\text { Pregnenolone } \\
\text { (ng/mg protein) }\end{array}$ & $\begin{array}{l}\text { Progesterone } \\
\text { (ng/mg protein) }\end{array}$ \\
\hline Control & $522 \cdot 4 \pm 29 \cdot 2$ & $400 \cdot 9 \pm 21 \cdot 7$ \\
\hline SNP (1 mM) & $302 \cdot 0 \pm 10 \cdot 4^{* *}$ & $221 \cdot 6 \pm 17 \cdot 2^{* *}$ \\
\hline ACTH $(1 \mathrm{ng} / \mathrm{ml})$ & $735 \cdot 2 \pm 49 \cdot 7$ & $633 \cdot 3 \pm 14 \cdot 1$ \\
\hline ACTH $(1 \mathrm{ng} / \mathrm{ml})+\mathrm{SNP}(1 \mathrm{mM})$ & $491 \cdot 6 \pm 43 \cdot 7^{* *}$ & $454 \cdot 3 \pm 29 \cdot 0^{* *}$ \\
\hline
\end{tabular}

together with the prevention by pregnenolone of SNP inhibitory effect, suggests that the decrease in corticosterone production is unlikely to be a result of an increase in cell death and is rather associated with NO effects on certain specific points along the steroidogenic pathway.

SNP and other NO donors inhibited basal and ACTHstimulated steroid biosynthesis in a dose-dependent manner. The effect of both SNP and DEA/NO was already evident at $50-100 \mu \mathrm{M}$, while $250-500 \mu \mathrm{M}$ was the threshold for DETA/NO and SNAP effects. Presumably, the higher concentrations required to attain a significant effect are related to the longer half-lives of these compounds.

This inhibitory effect is in agreement with the report by Adams et al. (1991) in which the in vivo stimulatory effect of L-NAME suggested that testicular and adrenal steroidogenesis are negatively regulated by endogenous NO. However, it has been shown that the administration of L-NAME induces the activation of the hypothalamicpituitary-adrenal axis through an increase of ACTH plasma levels (Giordano et al. 1996). Since these experiments were performed in vivo, systemic effects induced by the inhibition of the basal NO tone, such as an increase in blood pressure (Cameron \& Hinson 1993) cannot be ruled out.

As SNP and other NO donor effects were assessed in isolated cells, the results reported herein suggest, for the first time, a direct effect of $\mathrm{NO}$ on zona fasciculata steroidogenesis. Moreover, an inhibitor of NOS, L-NNA, significantly increased basal and ACTH-stimulated corticosterone production in zona fasciculata cells, suggesting a possible modulatory role for endogenously produced NO. Also in this sense, L-arginine not only significantly inhibited basal and ACTH-induced steroidogenesis, but prevented L-NNA stimulation of corticosterone production. 
There is much evidence to suggest that NO might act via the activation of soluble guanylate cyclase (Ignarro 1989, Snyder \& Bredt 1991). Although it has been demonstrated that NO also increases cGMP levels in adrenal cells (Palacios et al. 1989), exposure to the nucleotide permeable analogs $8 \mathrm{Br}-$ and db-cGMP did not reproduce the effect of SNP either on basal or on ACTH-stimulated adrenal steroidogenesis. This suggests, as has been reported for other steroidogenic cells (Van Voorhis et al. 1994, Del Punta et al. 1996), that the cGMP pathway is not involved in the NO-mediated regulation of steroidogenesis. The increase in corticosterone production elicited by the highest concentration of $8 \mathrm{Br}-\mathrm{cGMP}$ could reflect its stimulation of the cAMP-dependent protein kinase, as has already been described (Lincoln \& Cornwell 1993).

In order to determine the site of action of SNP along the steroidogenic pathway, corticosterone biosynthesis was examined under different stimuli. As shown in Table 2, SNP significantly inhibited the steroidogenesis stimulated by $8 \mathrm{Br}-\mathrm{cAMP}$ and $22(\mathrm{R})-\mathrm{OH}$-cholesterol, but was ineffective in the presence of exogenous pregnenolone. These results suggest that the NO site(s) of action must be at least at a step beyond cAMP synthesis and cholesterol transport between the mitochondrial membranes, but not after pregnenolone synthesis. In fact, SNP also inhibited pregnenolone and progesterone synthesis from endogenous cholesterol. Moreover, the conversion of $\left[{ }^{3} \mathrm{H}\right]$ cholesterol to $\left[{ }^{3} \mathrm{H}\right]$ pregnenolone, as an index of cytochrome P450 scc activity, was significantly inhibited by SNP. As this assay involves preincubation of adrenal glands in the presence of SNP, and the loading of mitochondria with the radiolabeled compound, both a decrease in the availability of $\left[{ }^{3} \mathrm{H}\right]$ cholesterol to the enzyme and the inhibition of $\left[{ }^{3} \mathrm{H}\right]$ cholesterol to $\left[{ }^{3} \mathrm{H}\right]$ pregnenolone conversion itself may account for the results reported herein. However, as 22(R)-OH-cholesterol stimulation of corticosterone synthesis was still impaired by SNP, the activity of the cytochrome P450 scc appears as a target for SNP action. The existence of an additional effect of SNP on cholesterol transport between the mitochondrial membranes is under current investigation.

The molecular events triggered by SNP that could explain these effects remain to be established. It has been shown that NO reacts directly with heme or nonheme iron and iron-sulfur complexes, located either at the active or allosteric site of key enzymes, producing activation or inhibition (Bredt \& Snyder 1994). Indeed, this is the proposed mechanism for the activation of soluble guanylate cyclase (Moncada et al. 1991, Bredt \& Snyder 1992, Schmidt 1992). Since it has been reported that NO inhibits hepatic cytochrome P450 enzymes both in vitro and in vivo (Wink et al. 1993) by binding to the heme moiety of the protein, it is tempting to speculate that the effect of $\mathrm{NO}$ on adrenal steroidogenesis could be explained by this mechanism. On the other hand, P450 enzymes have a conserved cysteine residue whose sulfhydryl group projects towards the heme. This sulfur is thought to interact with the iron during the catalytic process. Whether nitrosylation of that cysteine of rat adrenal cytochrome P450 scc occurs, as has been proposed for the mechanism of NO-induced inhibition of aromatase activity in granulosa-luteal cells (Snyder et al. 1996), deserves further examination.

As the metabolism of exogenously added pregnenolone was not impaired by SNP, the other P450 enzymes involved in the conversion of pregnenolone to corticosterone (e.g. the 21-hydroxylase from the endoplasmic reticulum, and the mitochondrial 11 $\beta$-hydroxylase) seemed not to be significantly affected by SNP. The reasons for this apparent specificity are not clear.

The physiological relevance of the present results awaits further investigation. However, the identification of NOS activity in rat zona fasciculata cells (Palacios et al. 1989), together with the significant inhibitory effect of several NO donors, and the fact that an inhibitor of this enzyme increases the production of corticosterone support the hypothesis that NO may play a role as a paracrine or autocrine regulator of adrenal steroidogenesis. Moreover, NO donors also partially prevented ACTH-induced steroidogenesis. The role of ACTH as a pleiotropic regulator in the zona fasciculata of the adrenal gland is well known. The existence of signals able to modulate its function, even partially, may contribute to the avoidance of an 'all-or-none' kind of response, providing the gland with a higher capacity to respond to a wide range of physiological demands. In this context, we consider that NO should be included in this category of biological modulators.

\section{Acknowledgements}

We wish to thank Dr Ruth Rosenstein for her invaluable and helpful suggestions. Thanks are also due to $\mathrm{Dr} \mathrm{C}$ Mendez and Dr D Golombek for critical reading of this manuscript. This work was supported by grants from Universidad de Buenos Aires (project ME 023) and Fundación Antorchas.

\section{References}

Adams ML, Nock B, Truong R \& Cicero TJ 1991 Nitric oxide control of steroidogenesis: endocrine effects of $\mathrm{N}^{\mathrm{G}}$-nitro-L-arginine and comparisons to alcohol. Life Sciences 50 35-40.

Bredt DS \& Snyder SH 1989 Nitric oxide mediates glutamate-linked enhancement of cGMP levels in the cerebellum. Proceedings of the National Academy of Sciences of the USA 86 9030-9033.

Bredt DS \& Snyder SH 1992 Nitric oxide, a novel neuronal messenger. Neuron 8 3-11.

Bredt DS \& Snyder SH 1994 Nitric oxide: a physiologic messenger molecule. Annual Review of Biochemistry 63 175-195. 
Cameron LA \& Hinson JP 1993 The role of nitric oxide derived from L-arginine in the control of steroidogenesis, and perfusion medium flow rate in the isolated perfused rat adrenal gland. Journal of Endocrinology 139 415-423.

Ceccatelli S, Hultin AL, Zhang X, Gustafsson L, Villar M \& Hökfelt T 1993 Nitric oxide synthase in the rat anterior pituitary gland and the role of nitric oxide in the regulation of luteinizing hormone secretion. Proceedings of the National Academy of Sciences of the USA 90 11292-11296.

Dave S, Farrance DP \& Whitehead SA 1997 Evidence that nitric oxide inhibits steroidogenesis in cultured rat granulosa cells. Clinical Science 92 277-284.

Del Punta K, Charreau EH \& Pignataro OP 1996 Nitric oxide inhibits Leydig cell steroidogenesis. Endocrinology 137 5337-5343.

Duvilansky BH, Zambruno C, Seilicovich A, Pisera D, Lasaga M, Díaz MC, Belova N, Rettori V \& McCann SM 1995 Role of nitric oxide in control of prolactin release by the adenohypophysis. Proceedings of the National Academy of Sciences of the USA 92 170-174.

Farese R 1970 Inhibition of cholesterol side chain cleavage by cyanoketone. Steroids 15 245-250.

Giordano M, Vermeulen M, Trevani A, Dran G, Andonegui G \& Geffner JR 1996 Nitric oxide synthase inhibitors enhance plasma levels of corticosterone and ACTH. Acta Physiologica Scandinavica 157 259-264.

Ientile R, Picciurro V, Pedale S, Nucci C, Malecka B, Nistico G \& Macaione S 1996 Nitric oxide enhances amino acid release from immature chick embryo retina. Neuroscience Letters 219 79-82.

Ignarro LJ 1989 Endothelium-derived nitric oxide: actions and properties. FASEB Journal 3 31-36.

Lincoln TM \& Cornwell TL 1993 Intracellular cyclic GMP receptor proteins. FASEB Journal 7 328-338.

Moncada S, Palmer RMJ \& Higgs EA 1991 Nitric oxide: physiology, pathophysiology and pharmacology. Pharmacological Reviews $\mathbf{4 3}$ 109-142.

Nakayama T, Izumi Y, Soma M \& Kanmatsuse K 1996 A nitric oxide synthesis inhibitor prevents the ACTH-stimulated production of aldosterone in rat adrenal gland. Endocrine Journal 43 157-162.

Natarajan R, Lanting L, Bai W, Bravo EL \& Nadler J 1997 The role of nitric oxide in the regulation of aldosterone synthesis by adrenal glomerulosa cells. Journal of Steroid Biochemistry and Molecular Biology $6147-53$.

Nathan C 1992 Nitric oxide as a secretory product of mammalian cells. FASEB Journal 6 3051-3064.
Neher R \& Milani A 1978 Steroidogenesis in isolated adrenal cells: excitation by calcium. Molecular and Cellular Endocrinology 9 243-253.

Neher R, Milani A, Solano A \& Podestá E 1982 Compartmentalization of corticotropin-dependent steroidogenic factors in adrenal cortex: evidence for a post-translational cascade in stimulation of cholesterol side chain split. Proceedings of the National Academy of Sciences of the USA 79 1727-1731.

Palacios M, Knowles RG, Palmer RMJ \& Moncada S 1989 Nitric oxide from L-arginine stimulates the soluble guanylate cyclase in adrenal glands. Biochemical and Biophysical Research Communications $165802-809$.

Rettori V, Belova N, Dees WL, Nyberg CL, Gimeno M \& McCann SM 1993 Role of nitric oxide in the control of luteinizing hormone-releasing hormone release in vivo and in vitro. Proceedings of the National Academy of Sciences of the USA 90 10130-10134.

Romero DG, Pecci A, Lantos CP \& Cozza EN 1996 Endothelin-1induced incorporation of cholesterol into rat adrenals. Steroids $\mathbf{6 1}$ 317-322.

Schmidt HHHW $1992 \mathrm{NO}, \mathrm{CO}$ and $\mathrm{OH}$ : endogenous soluble guanylyl cyclase-activating factors. FEBS Letters 307 102-107.

Schmidt HHHW, Warner TD, Ishii K, Shenk H \& Murad F 1992 Insulin secretion from pancreatic B cells caused by L-argininedelivered nitrogen oxides. Science 255 721-723.

Snyder GD, Holmes RW, Bates JN \& Van Voorhis BJ 1996 Nitric oxide inhibits aromatase activity: mechanisms of action. Journal of Steroid Biochemistry and Molecular Biology 58 63-69.

Snyder SH \& Bredt DS 1991 Nitric oxide as a neuronal messenger. Trends in Pharmacological Sciences 12 125-128.

Van Voorhis BJ, Dunn MS, Snyder GD \& Weiner CP 1994 Nitric oxide: an autocrine regulator of human granulosa-luteal cell steroidogenesis. Endocrinology 135 1799-1806.

Welch C, Watson ME, Poth M, Hong T \& Francis GL 1995 Evidence to suggest nitric oxide is an interstitial regulator of Leydig cell steroidogenesis. Metabolism 44 234-238.

Wink DA, Osawa Y, Darbybire JF, Jones CR, Eshenaur SC \& Nims RW 1993 Inhibition of cytochromes P450 by nitric oxide and a nitric oxide releasing agent. Archives of Biochemistry and Biophysics 300 115-123.

Received 20 October 1997

Revised manuscript received 8 January 1998 Accepted 11 March 1998 